\title{
Comparison of the ecotoxic properties of oil shale industry by-products to those of coal ash
}

\author{
Heidi Lees, Oliver Järvik, Alar Konist, Andres Siirde, Birgit Maaten*
}

Department of Energy Technology, Tallinn University of Technology, Ehitajate tee 5, 19086 Tallinn, Estonia

Received 11 June 2021, accepted 25 January 2022, available online 10 March 2022

\begin{abstract}
The European Union (EU) presented a uniform List of Waste (LoW) in 2000 and last updated the technical guidance in 2018. The respective local regulations for the classification of waste in Estonia were set in 2015. Due to the changes in the regulations, it was necessary to review the properties of solid wastes generated in Estonian oil shale industry in light of hazardous properties. Therefore, the properties of the produced ash streams were analysed and the obtained results were compared to those for coal for being in accordance with common practices. The main objective of the paper was to answer the question whether the properties of oil shale (OS) are comparable to those of coal as coal and its combustion residues were not considered hazardous waste in Europe, but the respective counterparts of oil shale were. The EU guidelines suggest the use of calculations based on trace element concentrations for the classification of hazardous property (HP) 14 - ecotoxic. Therefore, an extensive study was conducted to investigate the hazardous properties of all the solid residues from power plants operating on oil shale and shale oil production facilities. This paper describes one part of it - the trace element compositions of the major ash streams produced in the Estonian oil shale industry and focuses on their comparison with data available for coal ash samples. The findings of the study showed that, similarly to coal, oil shale ash (OSA) should not be considered as ecotoxic due to the low concentrations of trace elements. It was found that the investigated oil shale ash samples exhibited a very similar composition and properties to those of coal, and as a result of a larger study, from the beginning of 2020, oil shale ash and other oil shale thermal treatment residues are not classified as hazardous waste in Estonia, thereby initiating policy changes that affect most areas of the economy.
\end{abstract}

Keywords: oil shale by-products, solid fuels, ecotoxicity, heavy metals, waste policy.

\footnotetext{
* Corresponding author: e-mail birgit.maaten@taltech.ee

(C) 2022 Authors. This is an Open Access article distributed under the terms and conditions of the Creative Commons Attribution 4.0 International License CC BY 4.0 (http://creativecommons.org/licenses/by/4.0).
} 


\section{Introduction}

The main goal of environmental policies and regulations has been the mitigation of the impact of hazardous waste on the ecosystem and the health of the public, at the same time moving steadily towards greater resource recovery. Although most of the world is striving for renewable energy sources, several European countries are still highly dependent on fossil fuels for power production, Estonia being at the forefront with a total mining amount of 12.1 million tons in 2019 [1,2]. Therefore, as a result of thermal treatment, large amounts of solid waste are produced annually, which could potentially be used for different applications, depending on composition and properties. Until the end of 2019, oil shale ash (OSA) was considered as hazardous waste in Estonia and its uses were therefore quite limited.

Oil shale (OS) is known to have a high ash content, for specifically Estonian OS it may even be up to $50 \%$, and the ash is very rich in calcium [3]. Some examples of utilizing solid residues from oil shale industry include construction and the production of Portland cement [4], and fly ash (FA) could be used in different sorbents due to its considerable reactivity towards gaseous substances [5]. For coal ash, similar applications have been found in Thailand where foundry sand fly ash and electric arc furnace slag are used for the production of geopolymeric bricks with the share of fly ash being as high as $30 \%$ of the mixture [6]. Residues from shale oil production facilities - oil shale semicokes - have shown potential to be used in construction bricks, as soil ameliorators, chemicals, in cements, and others [7, 8]. In addition, their specific surface area was found to be moderately high, sufficient to be considered as potential sorbents [9]. Another interesting example is the possible use of oil shale ash as a binder in road construction materials in order to stabilise layers of the already existing base or to mass stabilise soft peat soils [10]. It should be noted that only less than $5 \%$ of the waste produced in Estonian oil shale industry finds beneficiary use [2]. This is a good example of how solid waste by-products could be repurposed and not dumped or otherwise disposed of and why this topic is of national interest.

Oil shale can be compared to coal as they both are mineral fossil fuels and might have somewhat similar properties, depending on geological origin. Many different methods have been proposed for the classification of coal types, some of which have been standardized. For example, in the United States (US) and some other countries as well, categorization was done using ASTM D388-19a [11], which is based on non-volatile carbon, volatile matter, heating value and sintering ability. The structure and formation of the organic material and mineral matter vary in large ranges, especially for coal. Therefore, in order to correctly evaluate and classify the properties of Estonian oil shale ash, it would be justified to follow handling practices for the classification of analogous waste, namely coal ash, produced in other countries of the world. Unlike oil shale, the ash streams from coal firing have been assigned 
entry codes, and were considered as non-hazardous wastes. According to the regulation, evaluation of their hazardous properties is therefore not necessary. When comparing the general composition and characterization of the two fuels, it can be concluded that oil shale exhibited a composition very similar to those of low rank coals (lignites). This was found to be an important detail in the future classification of oil shale combustion solid residues. Most of the entries of ash produced from coal were marked as absolute non-hazardous waste in the European Union (EU) Waste Framework Directive (WFD) [12]. Therefore, if oil shale ash were to exhibit similar properties to those of coal, it should be also considered as non-hazardous. However, oil shale ash was considered hazardous due to its high content of free calcium oxide and crystalline quartz [13]. It is also known that coal power and heat plants produce ash streams, the compositions of which have been found to vary in very large ranges [14]. This can be attributed to the type of coal used (lignite, (sub)bituminous coal, anthracite, etc.), but also depends on the utilised combustion technology. Similarly to the EU, coal ash has not been classified as hazardous waste by the US Environmental Protection Agency since 2014. The reclassification of coal ash into non-hazardous resulted in over $60 \%$ of the ash being repurposed in the US in 2017 and since then the trend has been increasing [15]. This is a good example of how the by-product of one industry can be used as raw material in another industry, thereby being in accordance with the modern industrial ecology concept [16].

Hazardous property 14 (HP 14), ecotoxicity, is described as "waste which presents or may present immediate or delayed risks for one or more sectors of the environment" [17]. No general guidelines or recommendations existed at the EU level on how to assess this property, and as a result, member states performed different types of analysis. The revised legislation from $2015 \mathrm{did}$ not specify it either since it was claimed that no satisfactory methodology could be developed at that time. The EU Council Regulation 2017/997 also stated that when both a laboratory test and the calculations based on concentrations are used, the results of the test should prevail [18]. However, the Regulation neither specifies which approach to use for the biological tests, nor has given any specific guidelines for assessing the acceptability of the results and for interpreting them (for example, how to take into account bioavailability and uptake). Currently, the EU suggests the use of four calculation methods, which are based on the trace element concentrations of the investigated samples. The precise guideline was provided only in the above EU Council Regulation 2017/997 [18]. The methods are best described by Hennebert et al. [19]. To sum up, elements were assigned different multiplication factors (M-factors), which take into account the toxicity and dangerousness of a specific element, with more hazardous elements and compounds ( $\mathrm{Hg}$ and PAHs, for example) having higher M-factor values (M-factors for $\mathrm{Hg}$, PAHs and As are 1000, 100 and 10 , respectively). In the end, it is just the concentrations of heavy metals that affect the final result. 
Estonia is still highly dependent on oil shale as fuel for power plants and therefore, huge amounts of alkaline ash, 7 to 8 million tons, are produced every year [20]. Therefore, the goal of this paper was to investigate the possible ecotoxic properties of all the ash streams produced in the Estonian oil shale industry by using their trace element concentrations. Although it would have been possible to analyse only two general types of samples bottom and fly ashes, in this paper, we investigated all the different types of fly ash streams produced in the facilities in order to fully evaluate the properties of the materials and when necessary, identify the streams with potentially toxic properties. The technical descriptions of the technologies can be found elsewhere and will not be discussed here [21-23]. The significance of the conducted study was illustrated by the fact that the results formed the basis for local policy changes, thereby offering new possibilities for research for the repurposing of oil shale industry by-products, and scopes for new economic sectors.

\section{Experimental}

Data presented in this paper was based on real industrial samples from five Estonian industrial facilities utilizing oil shale as fuel. The combustion residues were characterized by samples from two circulating fluidized bed combustion (CFBC) facilities at Auvere and Eesti power plants, CFBC Auvere and CFBC EPP, respectively, and a pulverized combustion facility (PC-NID). Shale oil production plant residues were investigated by analysing samples from Petroter facility (solid heat carrier technology) and Kiviter facility (VKG, gaseous heat carrier technology). The samples were gathered from the facilities operating on nominal load. The mass balance and distribution of the produced ash streams have been described in previous works and will not be shown here [23-26]. For generalization, the samples can be divided into two groups - bottom ash (BA) and fly ash. Fly ash includes all ash samples except bottom ash. In order to determine the properties of all the produced streams, the main samples collected were BA, economizer (ECO) and air preheater (APH) ashes, and ashes from four-field electrostatic precipitator (ESP1-4). In case of Auvere, a fifth ESP field (ESP5) and one fabric filter (FF) ash samples were also collected. For the PC-NID facility bottom, superheater (SH), economizer, cyclone (CYC) and NID ash samples were gathered. In case of Kiviter and Petroter facilities, only general ash samples were collected. Overall, 14 different types of samples were gathered, generating in total 23 different samples, which illustrate the major ash types of Estonian oil shale industry. The ash samples were dried and crushed to analytical size and analysed according to local standards. Trace elements were quantified using inductively coupled plasma mass spectrometry (ICP-MS) - Thermo iCAP Qc (by dissolving the samples in a mixture of nitric and hydrofluoric acid) and 
wavelength dispersive X-ray fluorescence spectroscopy (WD-XRF) with a Rigaku ZSX Primus II 4 kW. X-ray source was Rhodium anode 4 kW X-Ray tube with a $30 \mu \mathrm{m}$ window. The list of crystals in use included the following: RX25, PET, LiF(200), LiF(220), RX61F, RX75, Ge, RX4 and RX40. The average relative standard deviation for all measurements remained under $3 \%$, showing a sufficient homogeneity of the samples.

\section{Results and discussion}

Data found in the literature for the properties of coal varied in quite a large range. As the variability of the composition of coal has been shown to be very high, its toxicity has also been shown to vary from acutely toxic [27-31] to non-toxic [28-30, 32, 33]. The consensus based on the gathered data showed that fly ash was more toxic than bottom ash [34-36]. However, the results were highly dependent on the investigated sample and the test organism used [37]. The comparison of data regarding general composition and trace element concentrations gathered from the literature for different coals and oil shale can be found in Table 1 .

As can be concluded from the data presented in Table 1, Estonian oil shale can be considered quite similar to coal, more specifically to Ca-rich lignite type coals, based on the presented compositions. The trace element concentrations of coal were found to vary in large ranges and were dependent on the specific origin and diagenetic development. As, $\mathrm{Be}, \mathrm{B}, \mathrm{Cd}, \mathrm{Cr}, \mathrm{Co}, \mathrm{Pb}$, $\mathrm{Hg}$, Mh and Ni were considered as the most harmful elements for both human health and the environment [27]. Supported by its high Ca concentration, lignite waste is classified into class C (lime content $>20 \%$, hence sometimes named high-calcium fly ash), therefore it can be concluded that the furnace and fly ash streams produced during the combustion of Estonian oil shale should be addressed in a similar way as lignite ash streams. Compared to power plants operating on coal and lignite, the ones operating on oil shale produce 1.5 to 5 times more ash per produced energy unit, and only up to $2 \%$ of the produced material can be repurposed [40]. Currently, most of the produced ash is deposited in landfills. Taking into account that around 7 to 8 million tons of ash is produced annually, and the population of Estonia, a bit more than 5 tons of ash is being deposited each year per person.

The trace element concentrations of the analysed samples are given in Tables 2-4. Based on these it is possible to calculate the ecotoxicity as described by the European Council regulations [18] and also by Hennebert et al. [19]. The results of the calculation of the ecotoxicity values for these samples can be found elsewhere [41]. 


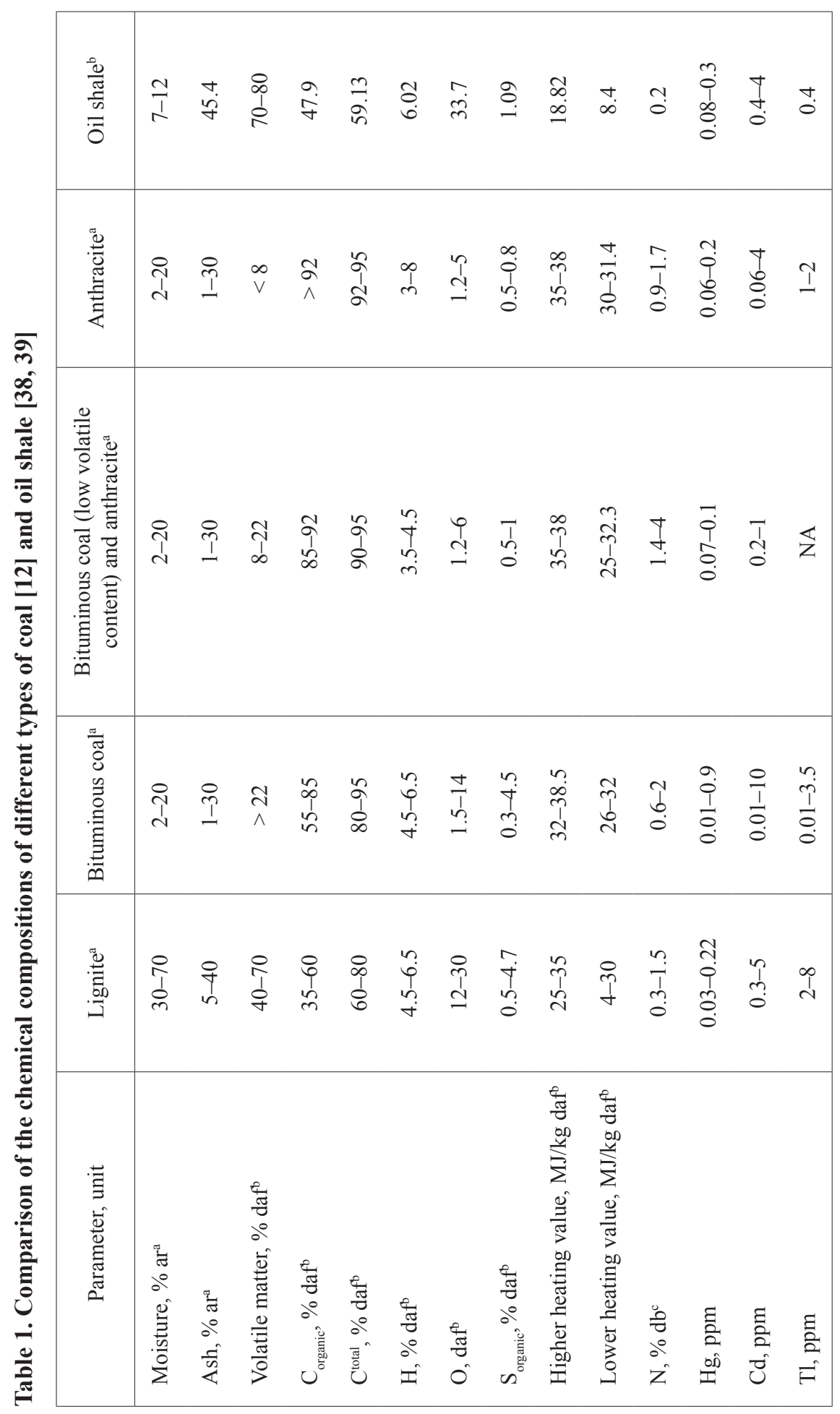




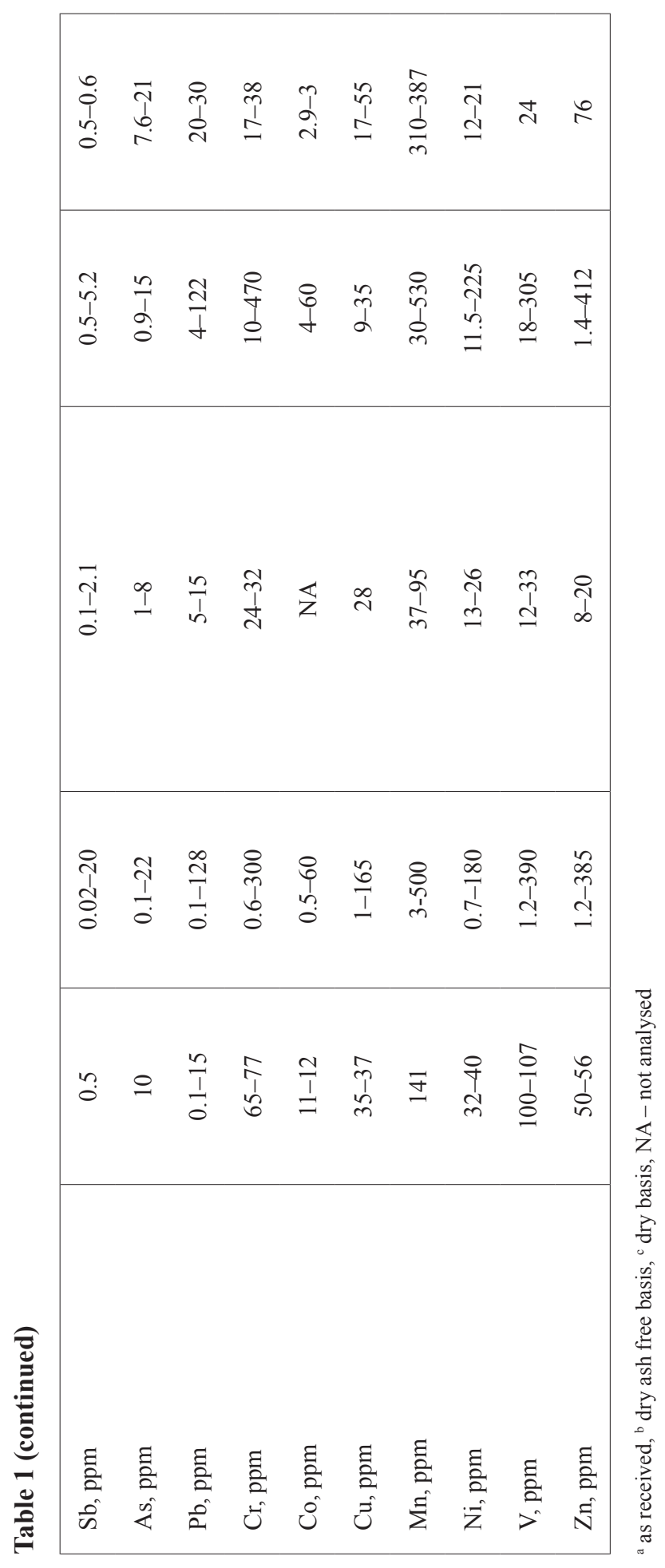


Table 2. Trace element composition of EPP CFBC oil shale ash samples, ppm

\begin{tabular}{|l|c|c|c|c|c|c|c|}
\hline Element & BA & ECO & APH & ESP1 & ESP2 & ESP3 & ESP4 \\
\hline $\mathrm{Mn}$ & 821 & 757 & 798 & 591 & 493 & 480 & 447 \\
$\mathrm{Ba}$ & 32 & 139 & 123 & 170 & 175 & 204 & 180 \\
$\mathrm{Zn}$ & 23 & 41 & 36 & 35 & 29 & 30 & 30 \\
$\mathrm{~Pb}$ & 17 & 58 & 38 & 63 & 52 & 69 & 61 \\
$\mathrm{~V}$ & 17 & 73 & 56 & 75 & 72 & 80 & 76 \\
$\mathrm{Cr}$ & 17 & 70 & 55 & 74 & 66 & 74 & 74 \\
$\mathrm{Ni}$ & 14 & 39 & 30 & 38 & 35 & 37 & 39 \\
$\mathrm{As}$ & 8 & 16 & 20 & 15 & 16 & 23 & 30 \\
$\mathrm{Cu}$ & 5 & 15 & 10 & 12 & 11 & 12 & 14 \\
$\mathrm{Mo}$ & 0.8 & 5.3 & 4.1 & 4.7 & 3.4 & 6.5 & 5.7 \\
$\mathrm{Co}$ & 2.5 & 7.6 & 6.1 & 7.8 & 6.6 & 7.2 & 7.6 \\
$\mathrm{Se}$ & 0.5 & 1.4 & 1.1 & 1.3 & 1.2 & 1.3 & 1.1 \\
$\mathrm{Ti}$ & 0.4 & 1.1 & 0.8 & 1.6 & 1.6 & 1.9 & 1.9 \\
$\mathrm{Tl}$ & 0.4 & 1.1 & 0.8 & 1.6 & 1.6 & 1.9 & 1.9 \\
$\mathrm{Sn}$ & 0.6 & 0.6 & 0.6 & 0.7 & 0.7 & 0.7 & 0.8 \\
$\mathrm{U}$ & 1.5 & 3.1 & 2.8 & 3.6 & 3.7 & 4.2 & 4.4 \\
$\mathrm{Sb}$ & 0.04 & 0.04 & 0.04 & 0.04 & 0.04 & 0.04 & 0.04 \\
$\mathrm{Cd}$ & 0.03 & 0.03 & 0.03 & 0.03 & 0.03 & 0.03 & 0.03 \\
$\mathrm{Hg}$ & 0.02 & 0.02 & 0.02 & 0.04 & 0.04 & 0.05 & 0.04 \\
$\mathrm{PAH}$ & 0.00 & 0.00 & 0.00 & 0.04 & 0.06 & 0.03 & 0.00 \\
\hline
\end{tabular}

As can be seen from Table 2, the most abundant trace level elements in EPP CFBC ash samples were Mn (447 to $821 \mathrm{ppm}$ ) and Ba (32 to $204 \mathrm{ppm}$ ). Elements like $\mathrm{Sn}, \mathrm{Sb}, \mathrm{Cd}$ and $\mathrm{Hg}$ exhibited concentrations less than $1 \mathrm{ppm}$, thereby not having a considerable influence on the ecotoxic properties of the investigated material even if the used multipliers were high. In general, the further away the ash stream from the boiler, the smaller the produced ash amount and the higher the concentration of trace element concentrations (for example, $\mathrm{Ba}, \mathrm{Pb}, \mathrm{V}, \mathrm{Cr}, \mathrm{Cu}$ and $\mathrm{As}$ ). This is with one exception - economizer ash. For the latter, most elements exhibited concentrations higher than the respective amount in the bottom ash, thereby indicating that the process 
conditions were such that the respective elements were stored in that ash stream. Only Mn exhibited an opposite trend - its concentrations decreased the further the stream from the boiler. The results indicate that the heavy metals were mostly accumulated into the finer particles of the ash samples. As described by Koukouzas et al. [42], the specific surface area values of the particles are in line with the particle size - the further the sampling point from the boiler, the smaller the particle and the larger the specific surface area.

Koukouzas et al. [42] have characterized the mobility of heavy metals in the CFB-derived coal fly ash. They analysed samples from the secondary cyclone, the cooler and the filter, and found that most of the elements of interest $(\mathrm{Cd}$, $\mathrm{Cr}, \mathrm{Cu}$ ) enriched the fine filter fly ash, whereas $\mathrm{Pb}$, for example, was mostly found in the cooler sample. The researchers also determined that fly ash samples from the cooler and the cyclone were intensely more siliceous and contained more $\mathrm{Al}_{2} \mathrm{O}_{3}$ (up to $24 \%$ and $35 \%$, respectively) than the bag filter sample due to a lower temperature of the latter sampling point. With respect to cyclone and cooler ashes, it was found that trace elements were almost equally distributed between the two. The results for EPP CFBC samples show that most elements exhibited the highest concentration values in the 4th field of the electrostatic precipitator ash sample.

Table 3. Trace element composition of Auvere CFBC oil shale ash samples, ppm

\begin{tabular}{|c|c|c|c|c|c|c|c|c|c|}
\hline Element & BA & ECO & APH & ESP1 & ESP2 & ESP3 & ESP4 & ESP5 & FF \\
\hline $\mathrm{Mn}$ & 808 & 566 & 669 & 729 & 676 & 506 & 563 & 517 & 490 \\
$\mathrm{Ba}$ & 0.2 & 0.2 & 0.2 & 0.2 & 0.2 & 0.2 & 0.2 & 253 & 0.2 \\
$\mathrm{Zn}$ & 279 & 117 & 129 & 198 & 104 & 96 & 97 & 77 & 66 \\
$\mathrm{~Pb}$ & 23 & 62 & 55 & 83 & 60 & 64 & 62 & 50 & 37 \\
$\mathrm{~V}$ & 19 & 54 & 49 & 71 & 61 & 73 & 80 & 60 & 52 \\
$\mathrm{Cr}$ & 16 & 52 & 47 & 60 & 55 & 66 & 66 & 57 & 51 \\
$\mathrm{Ni}$ & 20 & 30 & 28 & 42 & 31 & 38 & 39 & 28 & 27 \\
$\mathrm{As}$ & 53 & 21 & 31 & 29 & 27 & 37 & 57 & 54 & 46 \\
$\mathrm{Cu}$ & 4 & 10 & 9 & 13 & 10 & 14 & 13 & 10 & 8 \\
$\mathrm{Mo}$ & 6.7 & 7 & 7.2 & 10.4 & 8.4 & 19.1 & 26.3 & 19.8 & 18.5 \\
$\mathrm{Co}$ & 3.4 & 6.1 & 5.6 & 7.4 & 6.5 & 7.6 & 7.8 & 5.4 & 4.7 \\
$\mathrm{Se}$ & 0.5 & 0.9 & 0.9 & 0.9 & 1.1 & 1.2 & 1.5 & 1.4 & 1.1 \\
$\mathrm{Ti}$ & 1.3 & 0.7 & 0.9 & 1.3 & 4.6 & 1.6 & 1.8 & 1.6 & 1.2 \\
\hline
\end{tabular}


Table 3 (continued)

\begin{tabular}{|c|c|c|c|c|c|c|c|c|c|}
\hline $\mathrm{Tl}$ & 1.3 & 0.7 & 0.9 & 1.3 & 4.6 & 1.6 & 1.8 & 1.6 & 1.2 \\
$\mathrm{Sn}$ & 0.2 & 0.2 & 0.2 & 0.2 & 0.2 & 0.2 & 0.2 & 0.2 & 0.2 \\
$\mathrm{U}$ & 0.00 & 0.00 & 0.00 & 0.00 & 0.00 & 0.00 & 0.00 & 3.90 & 0.00 \\
$\mathrm{Sb}$ & 0.2 & 0.1 & 0.2 & 0.2 & 1.4 & 0.3 & 0.3 & 0.3 & 0.2 \\
$\mathrm{Cd}$ & 0.03 & 0.3 & 0.3 & 0.8 & 0.03 & 0.03 & 0.03 & 0.03 & 0.03 \\
$\mathrm{Hg}$ & 0.02 & 0.02 & 0.02 & 0.02 & 0.02 & 0.02 & 0.02 & 0.02 & 0.02 \\
\hline
\end{tabular}

As seen from Table 3, the elemental concentrations of Auvere CFBC ash samples exhibit similar magnitudes as the concentrations of the respective EPP CFBC samples. However, there are some exceptions, for example, in Auvere samples $\mathrm{Ba}$ was found to be present in noticeable concentrations only in the 5th field of the ESP with a concentration of $253 \mathrm{ppm}$, whereas for all the other samples the concentration remained around $0.2 \mathrm{ppm}$. The distribution of As also stood out - higher levels were detected in BA, the 4th and 5th fields of the electrostatic precipitator and the bag filter, with streams from the economizer to the 3 rd field of the electrostatic precipitator exhibiting almost two times lower values.

When comparing the results of the elemental concentrations of the ash streams from the two facilities, several trends were noticed. First, the BA trace element concentrations were mostly higher for Auvere sample. The highest differences were noticed for $\mathrm{Zn}$ and As with the respective amounts of 256 and $45 \mathrm{ppm}$. The average $\mathrm{Zn}$ concentration was much higher in Auvere samples. Mn followed a similar trend as $\mathrm{Zn}$ regarding distribution between the ash streams, but its concentration levels were in the same magnitude as those for EPP samples. These differences were attributed to both the oil shale used as feed and differences in the operating conditions of the facilities. Namely, EPP combustion temperatures were somewhat lower than those of Auvere power plant [43]. Although in different concentrations, the distribution of $\mathrm{Pb}, \mathrm{V}, \mathrm{Cr}$, $\mathrm{Cu}$ and $\mathrm{Ni}$ followed the same trend for all ash streams, showing a similar mobility under the given conditions. 
Table 4. Trace element composition of PC-NID plant, Petroter and Kiviter oil shale ash samples, ppm

\begin{tabular}{|c|c|c|c|c|c|c|c|}
\hline Element & BA & SH & $\begin{array}{c}\text { PC-NID } \\
\text { ECO }\end{array}$ & CYC & NID & $\begin{array}{l}\text { Petroter } \\
\text { general }\end{array}$ & $\begin{array}{l}\text { Kiviter } \\
\text { general }\end{array}$ \\
\hline $\mathrm{Mn}$ & 817 & 667 & 706 & 783 & 451 & 436 & 230 \\
\hline $\mathrm{Ba}$ & 107 & 143 & 132 & 154 & 0 & 124 & 54 \\
\hline $\mathrm{Zn}$ & 28 & 30 & 24 & 20 & 62 & 55 & 25 \\
\hline $\mathrm{Pb}$ & 13 & 30 & 28 & 26 & 74 & 40 & 41 \\
\hline $\mathrm{V}$ & 45 & 46 & 48 & 52 & 59 & 43 & 30 \\
\hline $\mathrm{Cr}$ & 38 & 39 & 42 & 46 & 63 & 34 & 24 \\
\hline $\mathrm{Ni}$ & 20 & 21 & 23 & 23 & 25 & 17 & 22 \\
\hline As & 8 & 8 & 11 & 8 & 25 & 10 & 8 \\
\hline $\mathrm{Cu}$ & 11 & 10 & 10 & 38 & 9 & 53 & 9 \\
\hline Mo & 0.2 & 0.3 & 0.9 & 0.3 & 4.1 & 3.4 & 4.1 \\
\hline Co & 4.5 & 4.5 & 4.9 & 5.0 & 5.3 & 3.2 & 3.2 \\
\hline $\mathrm{Se}$ & 0.9 & 0.9 & 1.0 & 1.0 & 1.3 & 0.5 & 0.5 \\
\hline $\mathrm{Ti}$ & 0.5 & 0.5 & 0.5 & 0.8 & 2.1 & 1700 & 1900 \\
\hline $\mathrm{Tl}$ & 0.5 & 0.5 & 0.5 & 0.8 & 2.1 & 0.1 & 0.1 \\
\hline Sn & 0.2 & 0.2 & 0.2 & 0.2 & 0.2 & 1.0 & 0.8 \\
\hline $\mathrm{U}$ & 2.5 & 2.7 & 3.0 & 2.9 & 0.00 & 2.8 & 3.2 \\
\hline $\mathrm{Sb}$ & 0.04 & 0.04 & 0.04 & 0.04 & 0.04 & 0.2 & 0.1 \\
\hline $\mathrm{Cd}$ & 0.03 & 0.03 & 0.03 & 0.03 & 0.03 & 0.2 & 0.1 \\
\hline $\mathrm{Hg}$ & 0.02 & 0.02 & 0.02 & 0.02 & 0.02 & 0.02 & 0.1 \\
\hline PAH & 0.00 & 0.00 & 0.00 & 0.00 & 0.11 & 1.13 & 3.80 \\
\hline
\end{tabular}

Based on the data presented in Table 4, it can be concluded that, as expected, the distribution of the elements into the ash streams was highly dependent on the conditions and process in the furnace and thermal treatment system. For example, in PC-NID samples, most of the elements exhibited different distribution patterns from those in CFBC samples. This was attributed to the 
differences in the temperatures and operating conditions - the temperatures in the PC boiler were significantly higher than in CFBC boilers, $1350-1450{ }^{\circ} \mathrm{C}$ and about $850{ }^{\circ} \mathrm{C}$, respectively [44]. Additionally, the grain size of the fuel was somewhat different. Elements like $\mathrm{Ni}, \mathrm{Zn}$ and $\mathrm{Pb}$ were expected to exhibit somewhat higher concentrations, up to $100 \mathrm{ppm}$, as they were related to the pyritization of limestone. As shown by Bityukova et al. [45], the higher temperature in the PC boiler resulted in the melting of clay minerals, generating reactive silica and aluminium. In contrast, in CFBC boilers the calcite minerals were not fully decomposed as some calcite was found in the produced ash, and the clay minerals were preserved. Additionally, Reinik et al. [46] investigated the release of specific elements from BA and FA samples of both PF and CFBC boilers and found their mobility to be higher in case of PF boiler ash than for CFBC boiler ash. The researchers found that $\mathrm{Sr}$ was the most mobile element in both sample types, with elements like $\mathrm{V}, \mathrm{Ni}$ and $\mathrm{Zn}$ having a generally low mobility. For the Petroter general sample, the elements concentrations remained generally low, with the exception of $\mathrm{Ti}$ (1700 ppm); the same was noticed for the Kiviter general sample. Petroter and Kiviter general samples were the only ones exhibiting PAHs in the range of 1-3 ppm, with CFBC and PC facility samples demonstrating concentrations significantly lower than $1 \mathrm{ppm}$. The general concentrations of PAHs have been found to be very low in previous studies [47-49]. Han et al. [50] found that during oil shale retorting, most of the heavy metals were retained in semicoke, although some tiny amounts of heavy metals were mobilized to other retorting products. This was noticed in the data presented in this paper as well, as elements like $\mathrm{Sb}, \mathrm{Cd}$ and $\mathrm{Hg}$ displayed higher concentrations compared to samples from combustion facilities.

In the REACH regulation [51], coal ash streams have been classified as being of unknown or variable composition, complex reaction products or biological materials. These also included ash streams produced during cocombustion, where coal or lignite was the primary fuel, and other solid fuels, coke, liquid and gaseous fuels could be the secondary fuel. This resulted in covering solid waste with a very wide range composition due to the different properties of the starting materials. The limits for the composition of ash streams produced during pulverized firing have been described by the European Coal Combustion Products Association. The amount of $\mathrm{CaO}$ has been shown to vary from $0.1-45 \%$ and $\mathrm{SiO}_{2}$ from $20-76 \%$. The material may contain up to $35 \%$ mullite and quartz. Regarding heavy metals and their concentrations, it was stated that for the concentration limit of 0.1 or $1 \%$, the elements were not present in such an amount that would require additional classification and labelling, thereby describing the material as non-hazardous. This was a direct indication of how computational methods would not yield a verdict of the material being hazardous since the elements did not exceed limit values. This was also the case described in the current paper and in a former work of ours [41] as none of the elements showed significant concentration levels. 
Based on the data presented in Tables 2-4, the general trend was that the concentrations of trace elements, including heavy metals, did not exceed the normative values set in Estonian regulations, for example, the limits for residential land for PAHs, As and Ba concentrations were 20, 30 and $750 \mathrm{ppm}$, respectively [52]. As shown by Loosaar et al. [53], the trace metal concentrations of landfilled ash were at the same level as their content in the ground. This was supported by the work of Kahru and Põllumaa [54] who reviewed the ecotoxicity of Estonian oil shale industry waste streams. The investigators concluded that both the ash and semicoke samples did not contain either heavy metals, PAHs or oil products at hazardous levels, although some waterextracted toxicity was noticed. In addition, the scientists determined that old semicoke samples were neutral and fresh ones acutely toxic and hazardous via solid waste-water path. This again illustrated the effect that the choice of sample and analysis method have on the outcome of an investigation and how policy changes at a national level require large scale studies and cannot be based on the results of a single paper only. The results of this paper demonstrated that the behaviour and distribution of elements in the ash streams exhibited a largely similar trend - the concentrations of all the heavy metals and other trace elements increased in the direction of finer particles, e.g. from BA to ESP streams. Based on these data, the most important conclusion was that the elemental concentrations in the samples remained low and did not exceed the norms set for service and residential land.

The use of computational methods assumed that all the components with ecotoxic properties have been determined, quantified and classified according to the CLP directives. As traditional chemical analysis methods might not detect all the chemical components, a conservative approach was used in computational methods by assuming that each element is present in its most harmful state. When the elements concentrations were below the limit of detection (LoD), the latter values were used in calculations. This amplifies the effect of some elements, but offers a buffer for reliable results. As there is currently no uniform test method in the EU for the evaluation of HP 14, the authors would suggest the use of an individual, a case-by-case approach for materials of complicated composition. This would enable taking into account the solubility of specific components instead of their general concentration and the dependence of ecotoxic properties on the concentration limit values set. As this property is crucial for the possible reuse of a huge amount of waste, the decisions regarding its evaluation must be thoroughly analysed and processed, specifically the long-term consequences, from the circular economy perspectives.

According to Eurostat, Estonia has been, among other European countries, at the forefront of the per capita waste generation since 2004. For example, in 2018, Estonia produced 9.3 million tons of hazardous waste from combustion. The severity of the situation is illustrated by the fact that the second highestproducing country was Germany with only 0.8 million tons, the difference 
being more than tenfold. Europe's total was around 12.5 million tons, which means that Estonia was responsible for almost $75 \%$ of this figure [55]. This statistics illustrate the importance of the correct characterization of waste as millions of tons of materials might be left unused and would instead be landfilled, thereby occupying land that could be used for other purposes. Additionally, the European Commission has changed the principles of funding future hazardous waste landfilling, supporting limited, exceptional cases only. As the transition towards a more circular economy has become increasingly important on a global level, the minimization of the production of waste is one of the key objectives. Raising awareness on a national level has also been emphasized [56].

Hazardous property 14 is important to be evaluated when a material under investigation has been assigned a mirror code. Mirror entries describe two or more related entries where one of them is hazardous and the other not. As the high $\mathrm{CaO} / \mathrm{Ca}(\mathrm{OH})_{2}$ combustion residues of lignite containing high levels of $\mathrm{CaO} / \mathrm{Ca}(\mathrm{OH})_{2}$ were classified as absolutely non-hazardous in the EU Waste Directive [57], it was proposed that oil shale industry by-products should be handled in a similar manner. In the European Union List of Waste (LoW), coal combustion by-products did not have mirror codes and were considered non-hazardous, although based on composition they might exhibit hazardous properties (HP 6 and HP 8). As stated in the Commission Directive, a mirror entry imposes an obligation to investigate the hazardousness of the material from the point of view of ecotoxicity [57]. Since 01.01 .2020 , mirror codes have no longer been used. The use of HP 14 is responsible for the decline in the production of hazardous waste in the world since the beginning of 2020, offering new possibilities for the repurposing of a large amount of material rich in composition.

The results presented in this paper allowed a conclusion to be made that considering heavy metal and trace element concentrations, the ash streams produced in Estonian oil shale industry exhibited a chemical composition comparable to that of lignite, which has been widely used in the energetic sector all around the world. The trace element concentrations were found to be lower than the respective literature values for coal. This leads to the conclusion that the composition of the bottom and fly ashes produced in Estonian oil shale industry should be regulated in the same way as that of coal-based BA and FA. This was found to be a good basis for initiating political changes as the fact that coal ash was considered non-hazardous suggested that oil shale industry by-products should be handled similarly. This would in turn offer new possibilities for cooperation with other countries via joint projects and research to introduce and further develop circular economy. To the best of the authors' knowledge, this is one of the first papers comparing the ecotoxic properties of Estonian oil shale ash to those of coal. 


\section{Conclusions}

The goal of this paper was to investigate the ecotoxic properties of all the ash streams produced in the Estonian oil shale industry and compare them to the respective data on coal, since coal thermal treatment solid products have not been considered hazardous waste in the countries still utilizing fossil fuels. This was done by gathering 23 samples from both combustion and oil production facilities and their hazardous property, ecotoxicity, was investigated to possibly re-evaluate the status of the hazardousness of the materials. The results formed the basis of computational methods proposed by the European Union to investigate hazardous property 14. Based on the results obtained, it was concluded that Estonia should not consider oil shale thermal treatment solid by-products as hazardous waste. In all the investigated samples, none of the concentrations exceeded the normative values set by the European Union and the concentrations were lower than the respective literature values for coal. As proven by the computational methods used, the investigated samples did not exhibit ecotoxic properties. As a result of the study, the material was removed from the list of hazardous substances, starting from the 1 st of January 2020. This is a very important outcome as it opened up new and easier possibilities for the repurposing of the material, thereby enabling lesser landfilling. Such changes on a national level offer new possibilities for research and might expand the existing sectors of the economy.

\section{REFERENCES}

1. Siirde, A. Oil shale - global solution or part of the problem? Oil Shale, 2008, 25(2), 201-202.

2. Paiste, P., Külaviir, M., Paaver, P., Heinmaa, I., Vahur, S., Kirsimäe, K. Beneficiation of oil shale processing waste: secondary binder phases in alkali activated composites. Waste Biomass Valori., 2019, 10(5), 1407-1417.

3. Maaten, B., Konist, A., Siirde, A. High-speed thermogravimetric analysis of the combustion of wood and Ca-rich fuel. J. Therm. Anal. Calorim., 2019, 138(4), 2807-2811.

4. Irha, N., Reinik, J., Jefimova, J., Koroljova, A., Raado, L.-M., Hain, T., Uibu, M., Kuusik, R. PAHs in leachates from thermal power plant wastes and ash-based construction materials. Environ. Sci. Pollut. Res., 2015, 22(15), 11877-11889.

5. Kaljuvee, T., Trass, O., Pihu, T., Konist, A., Kuusik, R. Activation and reactivity of Estonian oil shale cyclone ash towards $\mathrm{SO}_{2}$ binding. J. Therm. Anal. Calorim., 2015, 121(1), 19-28.

6. Apithanyasai, S., Supakata, N., Papong, S. The potential of industrial waste: using foundry sand with fly ash and electric arc furnace slag for geopolymer brick production. Heliyon, 2020, 6(3), e03697. 
7. Taulbee, D. N., Graham, U. M., Carter, S. D., Robl, T. L., Derbyshire, F. Examination of eastern US oil shale by-products and their markets. Fuel, 1995, 74(8), $1118-1124$.

8. Akar, A., Ekinci, E. Production of chemicals from oil shales. Fuel, 1995, 74(8), $1113-1117$.

9. Külaots, I., Goldfarb, J. L., Suuberg, E. M. Characterization of Chinese, American and Estonian oil shale semicokes and their sorptive potential. Fuel, 2010, 89(11), 3300-3306.

10. Pototski, A. Estonian Environmental Strategy, 2013 (in Estonian).

11. ASTM International, "ASTM D388-19a, Standard Classification of Coals by Rank," West Conshohocken, PA, 2019.

12. European Commission. Regulation (EC) No. 1357/2014 of 18 December 2014 Replacing Annex III to Directive 2008/98/EC of the European Parliament and the Council on Waste and Repealing Certain Directives. 2014.

13. Tallinn University of Technology and University of Tartu. Potential Hazardousness of Estonian Oil Shale Ashes, Tallinn, 2019, 1-184 (in Estonian).

14. Lecomte, T., Ferreria De La Fuente, J., Neuwahl, F., Canova, M., Pinasseau, A., Jankov, I., Brinkmann, T., Roudier, S., Delgado Sancho, L. Best Available Techniques (BAT) Reference Document for Large Combustion Plants. Publications Office of the European Union, Luxembourg, 2017.

15. Environmental Protection Agency. Hazardous and Solid Waste Management System: Disposal of Coal Combustion Residuals from Electric Utilities; Amendments to the National Minimum Criteria (Phase One, Part One), 2018, 36435-36456.

16. Heidrich, C., Feuerborn, H.-J., Weir, A. Coal combustion products: a global perspective. In: World of Coal Ash (WOCA) Conference, 22-25 April 2013, Lexington, KY.

17. European Commission. Commission Notice on Technical Guidance on the Classification of Waste. Official Journal of the European Union, OJ C 124, 9.4.2018, 1-134.

18. The European Parliament and the Council of the European Union. Council Regulation (EU) 2017/997 amending Annex III to Directive 2008/98/EC of the European Parliament and of the Council as regards the hazardous property HP 14 'Ecotoxic'. 2017, 1-4.

19. Hennebert, P., Humez, N., Conche, I., Bishop, I., Rebischung, F. Assessment of four calculation methods proposed by the EC for waste hazardous property HP 14 'Ecotoxic'. Waste Manage., 2016, 48, 24-33.

20. Pihu, T., Konist, A., Puura, E., Liira, M., Kirsimäe, K. Properties and environmental impact of oil shale ash landfills. Oil Shale, 2019, 36(2), 257-270.

21. Arro, H., Prikk, A., Pihu, T., Öpik, I. Utilization of semi-coke of Estonian shale oil industry. Oil Shale, 2002, 19(2), 117-125.

22. Plamus, K., Soosaar, S., Ots, A., Neshumayev, D. Firing Estonian oil shale of higher quality in CFB boilers - environmental and economic impact. Oil Shale, 2011, 28(1S), 113-126.

23. Konist, A., Pihu, T., Neshumayev, D., Siirde, A. Oil shale pulverized firing: boiler efficiency, ash balance and flue gas composition. Oil Shale, 2013, 30(1), 6-18. 
24. Hotta, A., Parkkonen, R., Hiltunen, M., Arro, H., Loosaar, J., Parve, T., Pihu, T., Prikk, A., Tiikma, T. Experience of Estonian oil shale combustion based on CFB technology at Narva power plants. Oil Shale, 2005, 22(4S), 381-397.

25. Ots, A. et al. Influence of Oil Shale Composition to the Technical-Economical Indicators and Emissions of Energy Unit with CFBC Boilers, 2008 (in Estonian).

26. Pihu, T., Konist, A., Neshumayev, D., Loosaar, J., Siirde, A., Parve, T., Molodtsov, A. Short-term tests on firing oil shale fuel applying low-temperature vortex technology. Oil Shale, 2012, 29(1), 3-17.

27. Tsiridis, V., Petala, M., Samaras, P., Kungolos, A., Sakellaropoulos, G. P. Environmental hazard assessment of coal fly ashes using leaching and ecotoxicity tests. Ecotoxicol. Environ. Saf., 2012, 84, 212-220.

28. Baba, A., Kaya, A. Leaching characteristics of solid wastes from thermal power plants of western Turkey and comparison of toxicity methodologies. J. Environ. Manage., 2004, 73(3), 199-207.

29. Millemann, R. E., Parkhurst, B. R. Comparative toxicity of solid waste leachates to Daphnia magna. Environ. Int., 1980, 4(3), 255-260.

30. Suloway, J. J., Skelly, T. M., Roy, W. R., Dickerson, D. R., Schuller, R. M., Griffin, R. A. Chemical and Toxicological Properties of Coal Fly Ash. Environmental Geology Notes 105 (Illinois State Geological Survey Division), 1983.

31. Neufeld, R. D., Wallach, S. Chemical and toxicity analysis of leachates from coal conversion solid wastes. J. Water Pollut. Control Fed., 1984, 56(3, Part I), 266-273.

32. Palumbo, A. V., Tarver, J. R., Fagan, L. A., McNeilly, M. S., Ruther, R., Fisher, L. S., Amonette, J. E. Comparing metal leaching and toxicity from high $\mathrm{pH}$, low pH, and high ammonia fly ash. Fuel, 2007, 86(10-11), 1623-1630.

33. Bushumov, S. A., Korotkova, T. G., Ksandopulo, S. J., Solonnikova, N. V., Demin, V. I. Determination of the hazard class of ash after coal combustion by the method of biotesting. Orient. J. Chem., 2018, 34(1), 276-285.

34. Gallardo, S., van Hullebusch, E. D., Pangayao, D., Salido, B. M., Ronquillo, R. Chemical, leaching, and toxicity characteristics of coal ashes from circulating fluidized bed of a Philippine coal-fired power plant. Water Air Soil Pollut., 2015, 226(9), 312.

35. Skodras, G., Grammelis, P., Prokopidou, M., Kakaras, E., Sakellaropoulos, G. Chemical, leaching and toxicity characteristics of CFB combustion residues. Fuel, 2009, 88(7), 1201-1209.

36. Grammelis, P., Skodras, G., Prokopidou, M., Delvinquier, V., Lial, B., Kakaras, E., Sakellaropoulos, G. Investigations on the operating performance and ash toxicity of CFBC with imported coals. In: Proceedings of the 9th International Conference on Circulating Fluidized Beds, May 13-16, 2008, Hamburg, Germany, 1150.

37. Schwartz, G. E., Hower, J. C., Phillips, A. L., Rivera, N., Vengosh, A., Hsu-Kim, H. Ranking coal ash materials for their potential to leach arsenic and selenium: Relative importance of ash chemistry and site biogeochemistry. Environ. Eng. Sci., 2018, 35(7), 728-738. 
38. Arro, H., Prikk, A., Pihu, T. Calculation of qualitative and quantitative composition of Estonian oil shale and its combustion products. Part 2. Calculation on the basis of technical analysis data. Fuel, 2003, 82(18), 2197-2204.

39. Aunela-Tapola, L. A., Frandsen, F. J., Häsänen, E. K. Trace metal emissions from the Estonian oil shale fired power plant. Fuel Process. Technol., 1998, 57(1), 1-24.

40. Estonian Ministry of the Environment. National Development Plan for the Use of Oil Shale 2016-2030 - Report of 2016 and 2017. Tallinn, 2019 (in Estonian).

41. Lees, H., Järvik, O., Konist, A., Siirde, A., Maaten, B. Computational results of the ecotoxic analysis of fly and bottom ash from oil shale power plants and shale oil production facilities. Chem. Eng. Trans., 2020, 81, 967-972.

42. Koukouzas, N., Ketikidis, C., Itskos, G. Heavy metal characterization of CFBderived coal fly ash. Fuel Process. Technol., 2011, 92(3), 441-446.

43. Maaten, B., Konist, A., Siirde, A. Potential of solid residues from power plants as thermochemical energy storage materials. J. Therm. Anal. Calorim., 2020, 142(5), 1799-1805.

44. Arro, H., Pihu, T., Prikk, A., Rootamm, R., Konist, A. Comparison of ash from $\mathrm{PF}$ and CFB boilers and behaviour of ash in ash fields. In: Proceedings of the 20th International Conference on Fluidized Bed Combustion (Yue, G., Zhang, H., Zhao, C., Luo, Z., eds.), Springer, Berlin, Heidelberg, 2009, 1054-1060.

45. Bityukova, L., Mõtlep, R., Kirsimäe, K. Composition of oil shale ashes from pulverized firing and circulating fluidized-bed boiler in Narva thermal power plants, Estonia. Oil Shale, 2010, 27(4), 339-353.

46. Reinik, J., Irha, N., Steinnes, E., Urb, G., Jefimova, J., Piirisalu, E. Release of 22 elements from bottom and fly ash samples of oil shale fueled PF and CFB boilers by a two-cycle standard leaching test. Fuel Process. Technol., 2014, 124, $147-154$.

47. Kirso, U., Otson, R., Irha, N., Tanner, R., Tanner, H., Bogdanov, A. Some analytical problems concerning environment pollutants. Proc. Est. Acad. Sci. Chem., 1994, 43, 180-194.

48. Paalme, L., Voll, M., Urbas, E., Palvadre, R., Johannes, I., Kirso, U. Oil shale region influence on the atmospheric pollution of Lake Peipsi. Proc. Est. Acad. Sci. Chem., 1990, 39(1), 18-27 (in Estonian).

49. Kirso, U., Laja, M., Urb, G. Polycyclic aromatic hydrocarbons (PAH) in ash fractions of oil shale combustion: Fluidized bed vers pulverized firing. Oil Shale, 2005, 22(4S), 537-545.

50. Han, X., Külaots, I., Jiang, X., Suuberg, E. M. Review of oil shale semicoke and its combustion utilization. Fuel, 2014, 126, 143-161.

51. European Commission. "Regulation (EC) No 1907/2006 of the European Parliament and of the Council concerning the Registration, Evaluation, Authorisation and Restriction of Chemicals (REACH), establishing a European Chemicals Agency, amending Directive 1999/45/EC and repealing C," Off. J. Eur. Union, vol. 49, 2006. 
52. Regulation of the Government of the Republic of Estonia. Concentration limits for hazardous substances in soil. State Gaz. (Riigi Teataja), RT I 04.07.2019, 6 (in Estonian).

53. Loosaar, J., Parve, T., Konist, A. Environmental impact of Estonian oil shale CFB firing. In: Proceedings of the 20th International Conference on Fluidized Bed Combustion (Yue, G., Zhang, H., Zhao, C., Luo, Z., eds.), Springer, Berlin, Heidelberg, 2010, 422-428.

54. Kahru, U., Põllumaa, L. Environmental hazard of the waste streams of Estonian oil shale industry: An ecotoxicological review. Oil Shale, 2006, 23(1), 53-93.

55. Eurostat. Generation of Waste by Waste Category, Hazardousness and NACE Rev. 2 Activity, 2021.

56. European Commission. Communication from the Commission to the European Parliament, the Council, the European Economic and Social Committee and the Committee of the Regions - Closing the loop - An EU action plan for the Circular Economy, COM/2015/0614 final, 2015.

57. Commission Regulation (EU) No 1357/2014 of 18 December 2014 replacing Annex III to Directive 2008/98/EC of the European Parliament and of the Council on waste and repealing certain Directives. Official Journal of the European Union, OJ L 365, 19.12.2014, 89-96. 